\title{
3 次元モデルを用いた地盤調査リスク評価事例
}

\author{
林＼cjkstart義隆*・太田英将**
}

\section{要 旨}

地盤モデルを作成する場合，地質技術者は地質学の基本原理と彼らの調查経験を基にして作成する，一方，近年のIT化により 3 次元地 質モデルを作成するソフトウエアが発達し，害用に具されることになった。これらソフトウエアは地質技術者により区部された地層境界 や岩盤区分を柱状図から直接 3 次元で自動補間するばかりでなく, 地球統計学的手法を使って, 統計的な確からしさ(または不確実性)ま で数值で表現できるようになった。筆者らは，この地球統計学的手法を利用し，(1)地質調査におけるリスク評価を行った事例を示し，さ らに(2)リスクの階層性, (3)リスクコミュニケーションの事例について紹介する.

Key words：リスク risk, 不確実性 uncertainty, クリギング kriging, ボーリング調査 boring survey

\section{1. は じめ に}

「リスク」という言葉は，使用する立場や対象によって 異なる意味で用いられるので, 大津 ${ }^{1)}$ はリスクについて議 論する場合, 事前にその定義を行っておく必要があると述 ベている.

一般にリスクは図-1のように，A. 主観リスクとB. 客観 リスクに区分され，さらに客観リスクは，B-1. 土木工学 などの分野で用いられてきた定義とB-2. 金融工学の分野 で用いられてきた定義とに細分される。

A. 主観リスク

主観リスクとは，定量化できないリスクである，たとえ ば斜面崩壊の危険度は, 技術者の定性的な判断によって点
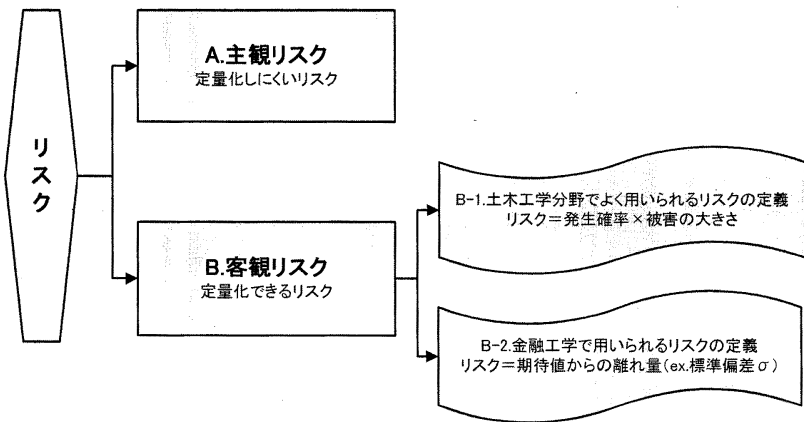

図-1リスクの定義

*(有)太田ジオリサーチ Ohta Geo Research Co.,Ltd.(会員) E-mail : hayashi@ohta-geo.co.jp

**(有)太田ジオリサーチ Ohta Geo Research Co.,Ltd.(会員)
数化することにより，定義される.

B. 客観リスク

客観リスクとは定量化できるリスクであり，土木工学分 野での定義と, 金融工学分野での定義とではその内容が異 なるので注意が必要である.

B-1. 土木工学分野での客観リスク

「リスク =発生確率×被害額の大きさ」によって定義さ れる，たとえば，落石被害リスクでは対象となる落石の発 生確率と落石が発生した場合の被害想定額の積で表される. B-2. 金融工学分野での客観リスク

「リスク＝期待值からの離れ量」によって定義される. たとえば，株価の変動予測において，統計処理をした予测 值からのばらつきがリスクとして定義され, 数学的には標 準偏差 $\sigma$ に相当する。つまり，金融工学分野においては, 金融商品の变動が期待值(リターン) どおりであるならば誰 にも損失は発生しないため, その期待値からのはずれ量が よ゙の程度となるかがリスクとして定義される。

\section{2.リスク評価の事例}

\section{1 工学的リスク評価の例}

モデルは，建築物基礎地盤の評価にかかわるあのである. 地盤は塊状の花崗岩類からなり, 基礎部分は電研式岩盤分 類によるCL級以上の岩盤が必要である。概略設計段階の 調査では計画地盤付近で一部DM〜DH級の岩盤が推定さ れた。このため, 当初設計に加えてDM級の岩盤について コンクリートで置き換える計画となっていた。 
今回の検討では，この置き換え範囲が適当であるかどう かの，リスク評価を行った．評価は，3次元的に岩盤区分 を地球統計学的手法で推定し, その的中確率の算出を行う 手法をとった.

3 次元岩盤区分は, COPSEY ${ }^{2)}$ にるジオロジックイン ジケータークリギング手法 (Geologic Indicator Kriging 以下「GIK」と称す)を用いた，本手法は，離散值である $\mathrm{CH}, \mathrm{CM}, \mathrm{CL}, \mathrm{D}$ 等の岩盤分類值を指標として, 空間上でそ

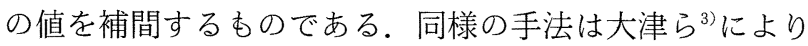
リスク工学の分野で本邦に紹介されている. 本手法を用い ると解析メッシュごとに岩盤分類を行い，その岩盤分類の 推定確率が算出される。この確率を用いて今回はリスク評 価を行うこととした。

本項では，リスクを土木工学分野での客観リスクの定義 「リスク＝発生確率×被害額の大きさ」に従って次のよう に定義する。

リスク＝岩盤分類の推定確率 $($ probability $) \times($ 追加 調査費用 + 当初想定以外の追加工事金額の 大きさ)

図-2は置き換え範囲周辺のGIKによる岩盤分類である. これによれば概略設計段階での置き換え範囲の外側にむさ らにDM級の岩盤が推定され，置き換え範囲の拡大が懸念 された

次に, 図-3に同じ範囲のDM級の存在確率を表示させる と, 現計画の置き換え範囲は確率が $0.8 \sim 1.0$ であるの対し, その外側 (図の右側)の存在確率は0.6と小さくなっている. 言い換えれば，この範囲はDMでない確率が 0.4 ということ であり，さらに追加ボーリングを行い，岩盤の性状を確認 してから設計変更したほうがよいと考えられた。

追加ボーリングの必要性については，上記のような定性 的な判断で行うことが一般的であるが，本稿では，これを リスクとして定量化することとした。

表-1には(1)このまま追加ボーリングをせず，置き換え範 囲を拡大した場合の費用と，(2)追加ボーリングをしてその 結果により設計変更する場合について比較した.

(1)追加ボーリングをしない場合とは，無条件で置き換え範 囲を拡大することに等しく，事象の発生確率は 1 として扱 うことであり，工事費用は当初から5,000千円が追加とな る.

(2)追加ボーリングをする場合は，追加ボーリング費用750 千円と追加工事費 5,000 千円が最悪の場合必要となるが, 現在推定したDM級の存在確率が 0.6 であるから, 工学的リ スクの定義式(1)より, リスク (損失期待値)は 3,450 千円之 なり，(1)の5,000千円よりあ小さくなる.

このように，今後の調查費用と追加工事費を地盤の推定 確率をパラメーターとしてリスク評価することにより, 追 加調査の意義を数量化することが可能である.

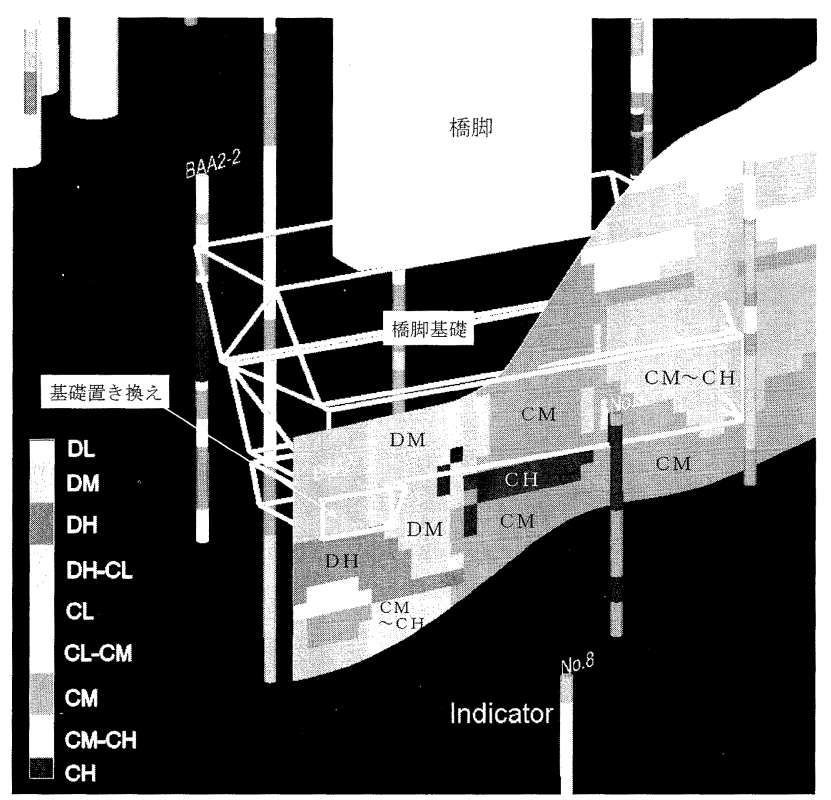

図-2ＧIKによる岩盤分類

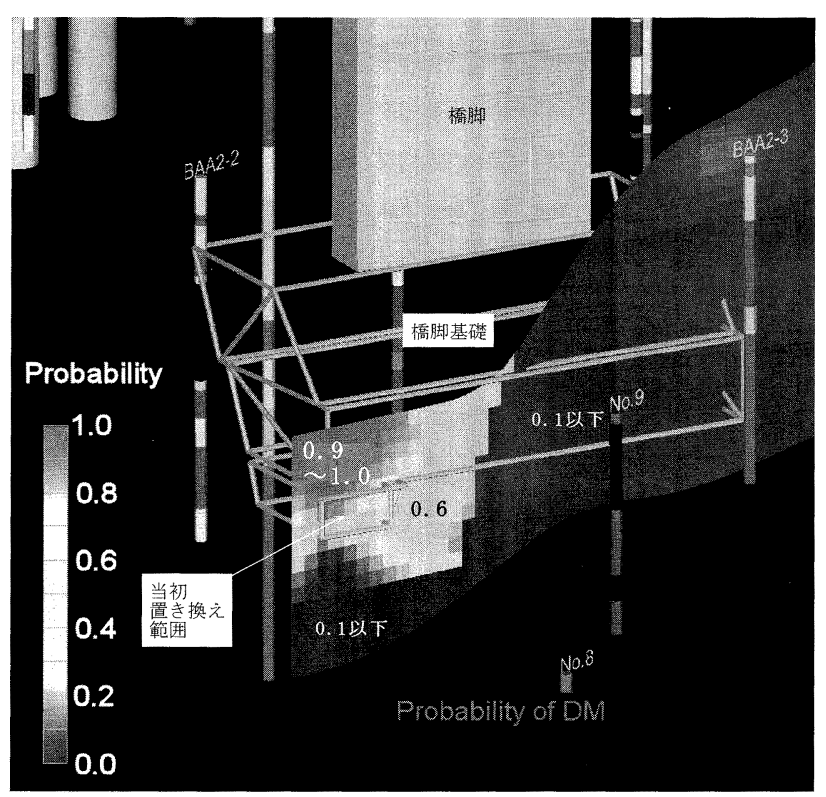

図-3 DM級の存在確率

表-1 工学的リスク算定

\begin{tabular}{|c|c|c|c|c|}
\hline \multicolumn{2}{|c|}{$\begin{array}{l}\text { リスク(千円) } \\
\text { 損失期待值 }\end{array}$} & $\begin{array}{c}\text { 調査費用 } \\
(千 丹)\end{array}$ & $\begin{array}{c}\text { 追加工事費用 } \\
(\text { 千円) }\end{array}$ & 発生確率 \\
\hline (1) & 5,000 & 0 & 5,000 & 1 \\
\hline (2) & 3,450 & 750 & 5,000 & 0.6 \\
\hline
\end{tabular}

なお，実際に追加調査を行った結果，CL級の岩盤が確 認され, 最終費用は追加調査分のみとなり, 経済的で施工 時点の手戻りのない設計を行うことができた.

このように, 岩盤分類にその存在確率という属性を持た せることにより, 追加調査位置の効果的な選定やその意義 の定量化を可能とし, 最小調査費用で, 最大の経済的な効 果をあげることができる(リスクの低減)可能性を示した。

\section{2 金融工学的リスク評価の例}

前章ではリスク $=$ 追加工事費用 $\times$ 発生確率とし, 追加調 査を行った場合のリスク（損失期待值）は3,450千円となっ 
表-2 金融工学的リスクの算定 追加調查前

最良シナリオとは，追加調查を行いその結果岩盤が良好で置き換え範囲は拡大しなかった場合に相当し，発生確率は調査前のDM級

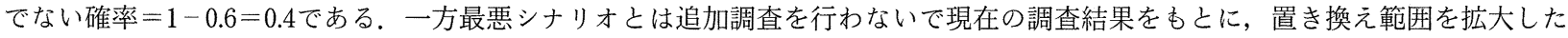
場合で発生確率はDM級の存在確率 $=0.6$ ある.

\begin{tabular}{|c|c|c|c|c|c|c|c|c|}
\hline \multicolumn{2}{|c|}{ シナリオ $r$} & $\begin{array}{l}\text { 調查費用 } \\
\text { (千丹) }\end{array}$ & 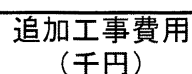 & 発生確率p & $\mathrm{p} * \mathrm{r}^{\wedge} 2$ & $\left(p *_{r}\right)$ & 期待値 $\mu$ & 標準偏差 $\sigma$ \\
\hline 最良 & 750 & 750 & 0 & 0.4 & 225000 & 300 & & \\
\hline 最悪 & 5,000 & 0 & 5,000 & 0.6 & 15000000 & 3000 & 3,300 & 2,082 \\
\hline
\end{tabular}

\section{表-3 金融工学的リスクの算定 追加調査後}

最良シナリオとは, 追加調查を行いその結果岩盤が良好で置き換え範囲は拡大しなかった場合に相当し, 発生確率は追加調查後のDM 級でない確率 $=1.0-0.1=0.9$ となる．一方最悪シナリオとは追加調査を行い置き換えが必要ないと判断したが，実際に工事の時点で 岩盤が不良となり結果的に置き換え範囲が拡大となった場合に相当し，発生確率は追加調查後に追加置き換え範囲がDM級である確 率0.1を用いる。

\begin{tabular}{|c|c|c|c|c|c|c|c|c|}
\hline \multicolumn{2}{|c|}{ シナリオ $r$} & 調査費用 & 追加工事費用 & 発生確率p & $p * r_{r} 2$ & $\left(p *_{r}\right)$ & 期待値 $\mu$ & 標準偏差 $\sigma$ \\
\hline 最良 & 750 & 750 & 0 & 0.9 & 506250 & 675 & & \\
\hline 最悪 & 5,750 & 750 & 5,000 & 0.1 & 3306250 & 575 & 1,250 & 1,500 \\
\hline
\end{tabular}

た。しかし，このリスクの確からしさがどの程度のあので あるかは，この式からだけではなかなか判断ができない。

本章では, リスクを金融工学で用いられる定義「リスク= 期待值からの離れ量」に基づいて次のように定める.

リスク $=$ 期待值の変動幅

期待值 (リターン) =予想される追加工事費用 (3)

金融工学的には, リスクとは期待值 (リターン)からのは ずれ量である，前章のモデルでは，予想される追加工事費 の変動幅ととらえることができ，よりリスクが明確になる あのと考えられる.

ここでは, 先のモデルに対して, 最良シナリオと最悪シ ナリオを想定し, それぞれの発生する確率を用いてリター ン(追加工事費用)とリスク (変動幅)を算出する.

追加工事費用の期待值

$\mu=P_{1} \times R_{1}+P_{2} \times R_{2}$

リスク (標準偏差)

$\sigma=\sqrt{\left[\left(P_{1} \times R_{1} \times R_{1}\right)+\left(P_{2} \times R_{2} \times R_{2}\right)-\left\{\left(P_{1} \times R_{1}\right)+\left(P_{2} \times R_{2}\right)\right\}^{2}\right]}$

$P_{1}, P_{2}$; 最悪および最良シナリオの発生する確率

$R_{1}, R_{2}$; 最悪および最良シナリオでの費用

上記式をモデルに適用した結果が表-2,3である.

表-2は追加調査前のリスクとリターンの関係, 表-3は追 加調査後の関係を示す.この結果を縦軸にリスク, 横軸に リターンをとって示したのが図-4である。図は金融工学の 分野では一般にリスク平面と呼ばれているあのであり，株 価の変動などにたとえればプロット点が左下に行けば行く ほどローリスク・ローリターン，右上に行くほど八イリス ク・ハイリターンと言われるあのである. ただし, 本モデ ルでは, ローリターンは追加工事費の減少であり, 事業者 にとっての利益となることが，株価の変動とは感覚的に異 なることに注意する必要がある。

この結果を見れば，追加調査を行った方が，よりリスク

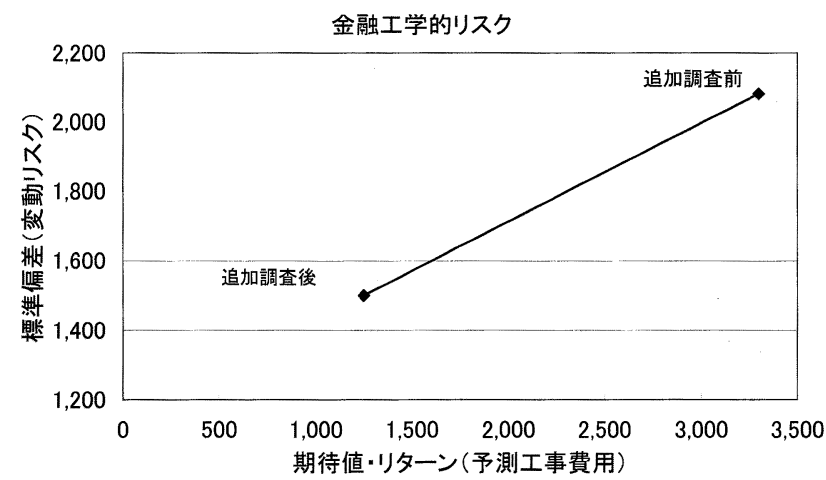

図-4 リスク平面

追加工事費用 (リターン)とその変動幅 (リスク)の関係を示 す図. 追加調査前は置き換え範囲の拡大の可能性が大きく, 追加工事費(リターン)抢よびその変動幅(リスク)む大きい (ハイリスク・ハイリターン), 一方調査後は, 置き換え範 囲拡大の確率が低くなり追加工事費用とその変動幅む小さ くなっている(ローリスク・ローリターン)

の少ない結果(期待值に対する変動幅が少ない)となること がわかる，すなわち，追加調査の実施によって予想される 工事費とその变動幅が減少することになり, 最小の費用で 最大の効果を上げていることが定量的に示された.

\section{3. リスクコミュニケーションの事例}

\section{1 リスクにおける階層性の認識}

本項では, 地盤污染量調査を例にとり, 調査手法の違い によるリスクのほかに, 調査結果を基に污染量を算出する 計算上のリスクが発生することを示し，リスクには階層性 があり，リスク評価をするうえでこの階層性についても理 解する必要があることを指摘する.

著者らは，ある污染現場においてメッシュ状にボーリン グ調査を行い污染範囲を推定した場合と，ボーリング時に オンサイトで污染量を測定し，調査精度の不確実性*を指 標として污染源を推定しながら調查を行った場合を比較し た ${ }^{4)}$ そその結果，図-5にあるように調査手法の違いにより その結果が大きく異なることが予想された．次に，3次元 


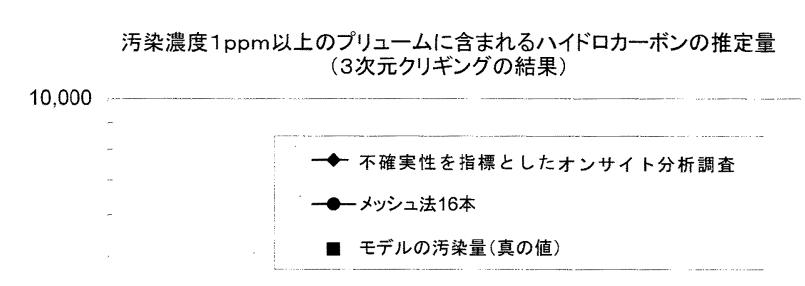

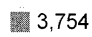

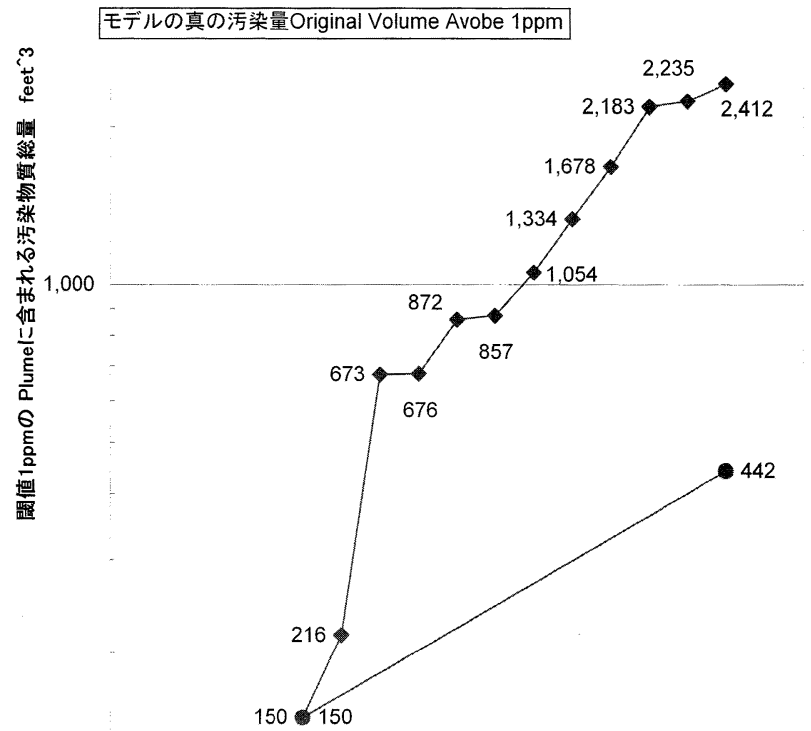

100

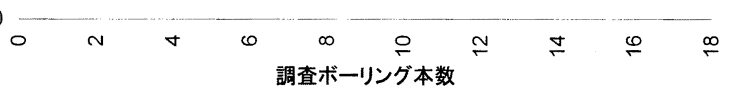

図-5＼cjkstart調查法の違いによる推定污染量の相違

$1 \mathrm{ppm}$ 以上の濃度の污染物質の総量を，100ft $(30.5 \mathrm{~m}) \times ッ$ シュの16本のボーリングと, 不確実性を指標としたオンサ イト分析調査により推定した場合との違い。不確実性 (uncertainty)は，クリギング手法によって推定された污 染地盤の濃度が高く, 汃, 既存調查点から離れており, デー夕の信頼度が低いことを数值化したもの. 数值が高い と不確実性が高い(信頼性が低い)と定義される。

クリギングによる污染量の推定方法によるリスクとして, 污染量推定值の最小值と最大值を算出し \% ，その振れ幅 を図-6に示した。この結果, まず上位のリスクとして調査 手法の違いによる調査リスクがあり,さらに下位のリスク として, 污染量計算手法による解析上のリスクがあること が明らかとなった。

以上のように，リスク評価を開示するにあたってはその 定義と用い方を明確にして説明し，一連の事業の中でどの 段階でどのようなリスクが存在し, 事業全体に与えるリス クの重要度をリスクの階層性を基に判断する必要があるも

※不確実性 (uncertainty)：クリギング手法によって推定され た污染地盤の濃度が高くかつ, 既存調查点から離れており, データの信頼度が低いことを数值化したもの. 数值が高いと 不確実性が高い(信頼性が低い)之定義される。

※※空間上の地点で計算した濃度の $60 \%$ が設定した閾値以下であ る場合を非超過確率 $60 \%$ 䦨値，40\%の場合を超過確率 $60 \%$ 䦨 値と定義し，推定最大值および最小值とした。

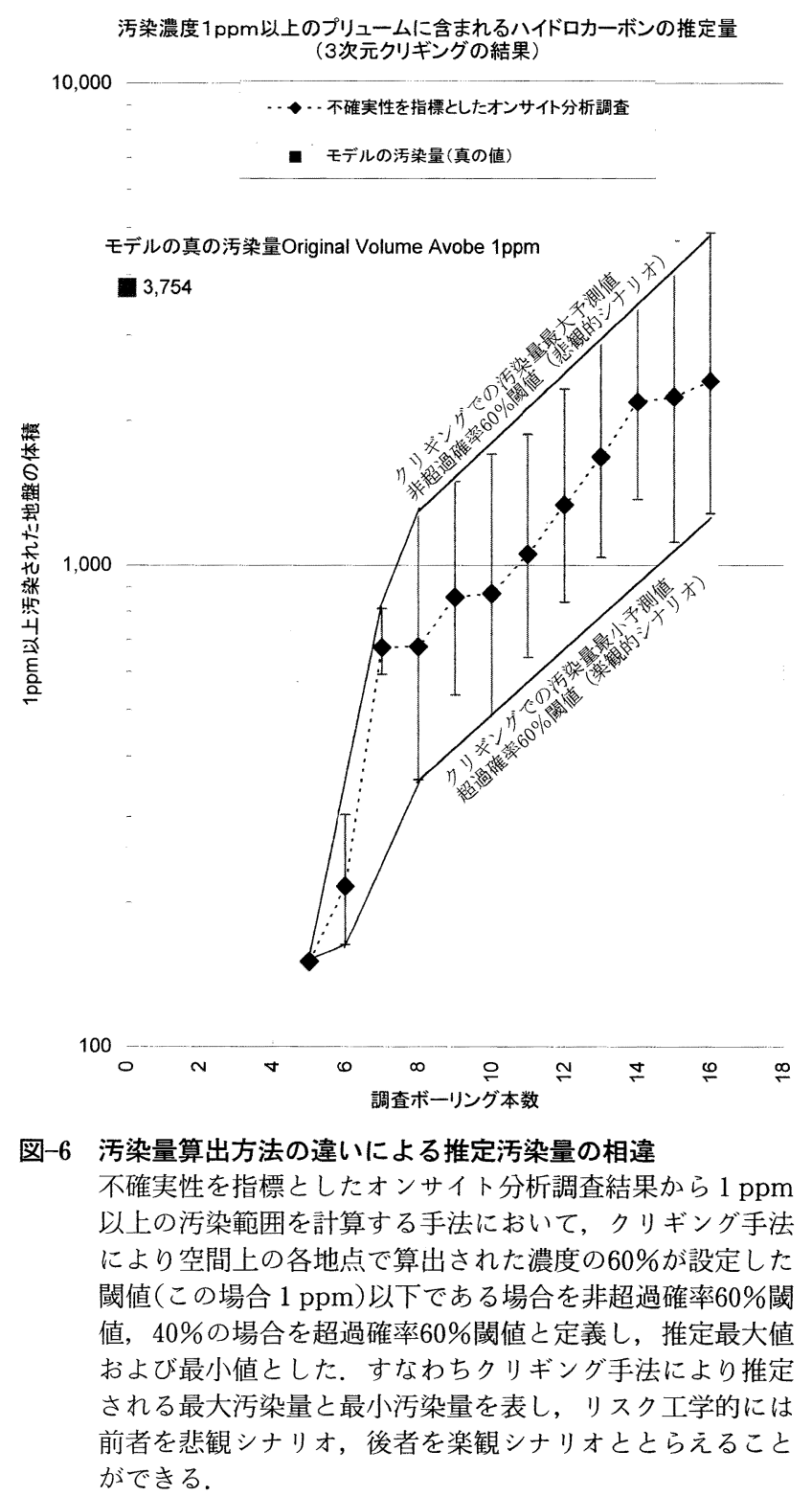

のと考えられた.

\section{2 リスクコミュニケーションの事例}

著者の所属した委員会報告 ${ }^{5}$ では, 架空の地盤污染現場 を想定し，浄化対策を行った場合の金融工学的リスクの算 出を行った(図-7)。污染対策は，(1)「掘削除去」と(2)「原 位置浄化」を想定し，それぞれにおける悲観的シナリオと 楽観的シナリオを作成し，污染量調査精度の違いを発生確 率として費用期待值 $\mu$ と費用の変動幅 $\sigma$ を算出し評価した。 その結果(2)「原位置浄化」は金融工学的にみると八イリ スク・ハイリターン型であり，(1)「掘削除去」よりあリス クが高く，事業主にとっては鬽ノの少ない工法であるとと がわかる。しかし，前項で述べたようなリスクを分析し， リスクの階層性でより上位の「調査方法の違いによるリス ク」を低減することによって, 図-7(3)「オンサイト調査に よる浄化」に示すような浄化費用之その变動幅の低減を実 現し, 掘削除去よりも魅力的な工法とする可能性もあると 思われる。 


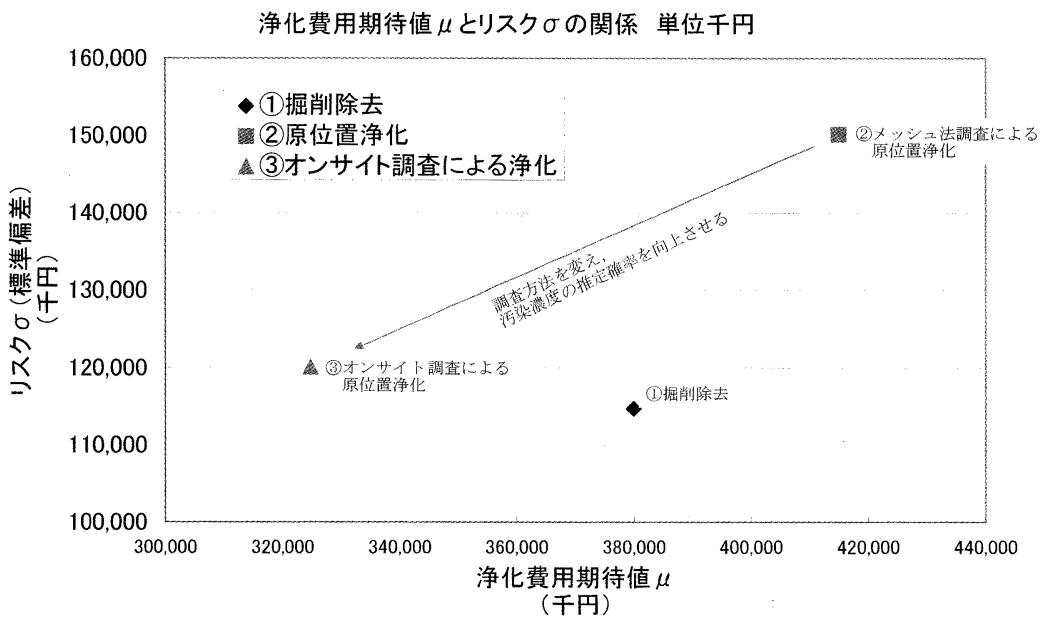

図-7＼cjkstart地盤污染浄化事業におけるリスク平面

污染現場の浄化費用(リターン)之その变動幅(リスク)の関係を示す図. メッ シュ法による機械的な調查による原位置浄化対策は浄化費用(リターン)およ びその変動幅（リスク）屯大きい(ハイリスク・ハイリターン), 一方污染濃度 をオンサイトで計測して不確実性を指標にした調查に基づく浄化対策では, 污染範囲が的確に把握できるため浄化費用, とその変動幅む小さくなり(ロー リスク・ローリターン), 掘削除去対策と比較できるまでになっている.
リスク評価は今後ますます重要になってく ると思われるが，大津 ${ }^{1)}$ が指摘したように， 土木工学や応用地質分野でリスクの概念を用 いる場合も，最初に「誰にとってのリスクか」 (リスクの主体)と，「リスクの算出方法」(リ スクの定義)を明確にすることが必要である と思われる。また，本稿で扱ったようなリス クの定量化は対象事業を進めるうえで有益な あのと思われるが， あくまで意志決定のため の一つの手段であること，また，リスクは絶 対不変の物ではなく，それぞれの事業段階や 受益対象によって常に変化することを理解す る必要があるあのと思われる。

\section{引用 文 献}

1）大津宏泰(2004)：5.ジオリスクエンジニアリン グ, リスク工学と地盤工学, 土と基礎, Vol. 52, No.7, pp. 27-34.

以上のように, 污染物質調査にリスク評価を適用するこ とで, リスクの所在とその低減方法を特定するだけでなく, 事業主とのリスクコミュニケーションにあ活用できると考 えられる。

\section{4. ま と め}

本稿では, 建築物基礎地盤調査の事例において, 土木工 学的なリスク評価に加え, 金融工学的なリスク評価の手法 を紹介した。 さらに, 地盤污染調査の事例で, リスクには 階層性があり，この認識の上にたってより上位の主要なり スクを特定し，その低減を図ることにより対策工法の評価 が変わることを示し，事業主とのリスクコミュニケーショ ンの一手段となることを示した.

2) Reed D. COPSEY (2005) : EVS and MVS Manuals Help and Tutorials version8.0 Workbook 10 Geostatistics in EVS/MVS,Ctech development. (http : //www.ctech.com/ publications/workbooks_and_help.htm参照)

3）大津宏康 - 尾ノ井芳樹 - 大西有三・高橋徹 - 坪倉辰雄 (2004): 力学的地盤リスク要因による建設コスト変動の評価に関する 研究, 土木学会論文集, No.756/VI-62, pp.117-129.

4) 林義隆・太田英将・國眼定 (2003)：3 次元空間解析による污染 地盤の調査数量と污染量の信頼性について, 地盤の環境計測 技術に関するシンポジゥム講演資料, 地盤工学会関西支部. （http：//www.ohta-geo.co.jp/x/hayashi/参照）

5）楠見晴重・地盤污染の環境評価拈よび拡散防止技術に関する 研究委員会 (2006)：地盤污染のリスク評価㧍よび調査対策, 第 1 章, (社)地盤工学会関西支部, pp.3-47.

（2007年 8 月 2 日受付, 2007 年11月 9 日受理）

Jour. Japan Soc. Eng. Geol., Vol.48, No.6, pp.299-303, 2008

\title{
Risk Analysis of Geologic Survey using 3 Dimensional Modeling
}

\author{
Yoshitaka HAYASHI and Hidemasa OHTA
}

\begin{abstract}
Geologic Model is used to make by engineers on his own carriers based on Geologic principles. On the other hand, 3D automatic geologic modeling softwares are dramatically developed in recent years. The softwares directly generate geologic boundary or rock classification in three dimensional fields from borehole logs that have been classificated by engineers. More over, some of them have GEO-STATISTIC features which indicate statistical probability or uncertainty. Authors present three case studies, 1.Risk analysis on geologic survey, 2. Hierarchy on risk and 3.Risk communication, by using these GEO-STATISTIC features.
\end{abstract}

Key words : risk, uncertainty, kriging, boring survey 